\title{
CONTRASTING MULTIPLE CHOICE AND CLOZE TASK ON STUDENT'S READING COMPREHENSION
}

\author{
Elyza Martiarini \\ Department of English Education, School of Language and Arts \\ University of Indraprasta PGRI \\ elyza.martia@gmail.com
}

\begin{abstract}
The objective of this research is to obtain an empirical data about contrasting student's reading comprehension by using two types of tests: Multiple Choice and Cloze Task. The research type was a comparative descriptive method. The subject consisted of 30 students of the fourth semester of English Department at University of Indraprasta PGRI in 2015-2016 academic year. The research data were collected by using pre-test and post-test. The result of data cultivation identified that based on test by using Multiple Choice, the average score (mean) was 69.3, median was 64.49, mode was 62.1, and deviation standard was 13.40. Whereas Cloze Task mean was 55.6, median was 52.86, mode was 50, and deviation standard was 9.97. On the basis of hypothesis test, $t_{\text {test }} 15.56$ was higher than table 1.67 . It assumed that the significance result both Multiple Choice and Cloze Task are different (contrastive), in which student's reading comprehension by Multiple Choice was higher than Cloze Task.
\end{abstract}

Keywords:Multiple Choice, Cloze Task, Student's Reading Comprehension

\begin{abstract}
Abstrak
Tujuan dari penelitian ini adalah untuk mengetahui perbedaan hasil pemahaman membaca siswa dengan menggunakan dua jenis tes yang berbeda, yaitu:Multiple Choice dan Cloze Task. Jenis penelitian ini adalah metode deskripsi perbandingan. Penelitian ini dilakukan terhadap 30 mahasiswa semester empat program studi Pendidikan Bahasa Inggris di Universitas Indraprasta PGRI tahun ajaran 2015-2016. Data diambil melalui pre-tes dan pos-tes. Hasil dari analisis data diperoleh bahwa berdasarkan tes menggunakan Multiple Choice, nilai rata-rata sebesar 69.3, median 64.49, modus 62.1 dan standar deviasi sebesar 13.40. sedangkan berdasarkan Cloze Task diperoleh nilai rata-rata sebesar 55.6, median 52.86, modus 50, dan standar deviasi 9.97. Kemudian berdasarkan dari uji hipotesis, nilai thitung sebesar 15.56 lebih tinggi dibandingkan dengan nilai ttabel yaitu sebesar 1.67. Dengan demikian dapat disimpulkan bahwa dari kedua tes yaitu Multiple Test dan Cloze Task memiliki perbedaan secara signifikan, di mana hasil pemahaman membaca siswa dengan menggunakan Multiple Choice lebih tinggi daripada dengan menggunakan Cloze Task.
\end{abstract}

Kata Kunci: Multiple Choice, Cloze Task, Pemahaman Membaca Siswa

\section{INTRODUCTION}

Reading is general activity, it means that the students will not only read any materials inside the classroom such as text-books in teaching and learning process, but also read magazines, newspapers, novels and other materials in English as their target language in outside and wider space. From these wide reading activities, students will absorb more vocabularies that will engage them for improving their skills in language competence. This real fact shows that reading can be special interest and attention.

Reading is not just sitting down at the desk with a dictionary and a note book, as we read, we have to allow our mind to accept and cultivate every knowledge and take us into a world of adventure which we would not normally 
entered, but unconsciously by reading we will know the use of words and the language itself.

Purpose of reading are similar for the beginner and the mature of reader. The level of thought that is required to achieve the same reading purpose varies with the difficulty of selection and the skill of the reader different authorities suggest a variety of purpose for reading. We believe that most of these can be organized into five categories: (1) finding main idea, (2) finding supporting details, (3) grasping the author's plan, (4) following the sequence of event or thought and (5) critically grasping the author's work.

Reading comprehension skill is the reading that provides more explanation about how to read and comprehend the whole understanding of the text. The successfulness reading comprehension skill involves the student's discovering the meaning needed to achieve the particular purposes set for, or by, him. It may be finding a particular piece of information, solving a problem through reading, working to understand an idea, or following a set of directions. It is important to note that these kinds of mental abilities are not those measured by standardized reading comprehension tests.

To determine the ability of students' reading, the teacher can conduct evaluation. There are several forms of exercises or tests that can be given by the teacher to the students including Multiple Choice (For Form Focused Criteria), Matching Task, Editing Task, Gap Filling Task, Cloze Task, Short Answer Task, Editing Longer Task Ordering Task, Information Transfer and etc.

Multiple choice or multiple-choice test is a test that has only one correct answer. Multiple choice is an objective test that can measure the learning outcomes of the various aspects. Multiple choices tests have advantages in terms of presentation and analysis, so that teachers can know the extent of students' understanding of the field of studies. While Cloze task is a test that removes a paragraph word, text, or problems that will be given to students. Cloze test has an advantage in assessing legibility and reading comprehension of students.

Reading comprehension assessments are the most common type of published reading test that is available. The most common reading comprehension assessment involves asking a student to read a passage of text that is leveled appropriately for the student, and then asking some explicit, detailed questions about the content of the text. There are some variations on reading comprehension assessments, however. For example, instead of explicit questions about facts directly presented in the text, the student could be asked to answer inferential questions about information which was implied by the text, or the student's comprehension might be tested by his or her ability to retell the story in the student's own words or to summarize the main idea or the moral of the story. Another common reading comprehension assessment is called a "cloze" task — words are omitted from the passage, and the student is asked to fill in the blanks with appropriate words. Also, student's reading comprehension can be assessed by asking them to read and follow simple instructions given on multiple choice.

\section{THEORETICAL REVIEW Multiple Choice Test}

Multiple-choice test is a test that contains a range of information which is incomplete, and to equip it is by choosing from a variety of alternatives 
that have been provided (Uno and Koni, 2014: 113).

Multiple Choice questions are one of the types of problems objective. Teachers and evaluators will be directed to provide assessment on students. The values of the subjectivity of the teacher will be neutralized along with answer choices that have been determined. No matter how many examinees who took part will be easier to perform the standardization process assessment (Pramono, 2014: 80)

There are some writing principles in the content of the material of a multiple-choice questions to be asked: about the construction formulation and language used. a) Material matter, to the material about which should always be filled is about to be in accordance with indicators, properly and logical choice answers, and only one correct answer key. b) Construction matter, which must be considered is the subject matter defined brief, clear, and unequivocal. The formulation of the subject matter and choice of answers should be a statement that needed it. The subject matter did not give clues to the answer key. The subject matter does not contain statements that a double negative. Long answer choices are relatively similar formulation. Multiple choices does not contain the statement "all the answer choices on any" or "all options on the top right answers". Choice answers in the form of numbers or time listed in order of the amount of value that number or chronology. Pictures, graphs, tables, diagrams and the like clearly and function. Those items do not rely on the answers to previous questions. c) use of language on items, criteria to be met in the matter is to use appropriate language with the rules, using communicative language, do not use the language of the applicable local (cultural bias), and response options not repeat the word/ group of words that is not a sense of unity. (Pramono, 2014: 81-88)

Based Ratnawulan and Rusdiana (2015: 196) multiple-choice test is an objective test that is widely used by teachers. This test can measure a broad knowledge with the domain level varies. Item multiple choice test has all the requirements as a good test in terms of objectivity, reliability, and distinguishing between students who succeed with students who failed. MCQ has standardize the measurement of the level of knowledge of the most simple or more complicated levels, ranging from the ability of understanding knowledge, mastery of concepts, until comparatively. MCQ can load all of it in the form of a question in accordance with the capability to be assessed.

Some of the capabilities can be assessed, among others familiar with the term, know the facts, recognize the principle, familiar methods and procedures, identify the use of facts and principles, interpret causality, assess methods and procedures, as well as observation and measurement. (Pramono, 2014: 93)

The advantages of multiple choice tests compared to the others are: a) have a wider range of material than the selection of another item. b) Teachers can measure various cognitive domains, ranging from the simplest stage to the most complex. c) Can be used in the test that consists of many participants. d) have a high level of objectivity. e) It is easier and faster in the assessment particularly when aided with the help of technology. f) have a higher level of reliability. (Pramono, 2014: 105)

It can be concluded that the multiple-choice test is a form of matter whose answer can be selected from multiple choice answers. This form of test questions can be assessed easily, quickly, and have a high objectivity. To 
arrange multiple choice test takes a long time and a huge cost and the difficulty of making a choice answers homogeneous.

\section{Cloze Test}

Cloze test introduced by Wilson L. Taylor in 1953, is a kind of test in the form of discourse with the number of words that emptied and asked to complete the words that are appropriate in vacant places to determine changes in ability (Dubay, 2004 : 27). Cloze means temporary closure process. Called by the temporary closure due to a number of words in discourse, it is removed or covered systematically to be filled by way of conjecture based on the contents of the discourse context. The truth of the answers will be seen from the original text of discourse. There are three ways to eliminate the word: a) Eliminate the words in a certain order consistently, regardless of the word. This is called the fixed-ratio method. For example, if the selected word is omitted it is said that all 5 , then every fifth word (whether foreign words, proper names, acronyms or abbreviations) consistently eliminated. This method is usually used when the words of the discourse was considered normal for the test filler. b) Eliminate the words in a certain order with the regulation in accordance with the requirements set test maker. For example, it will be eliminated when including a noun or a verb, or in other words the type specified by the test maker. This is called the variables-fixed ratio. This method is usually used when the test maker wants to know the level of difficulty of the words that belong to the kinds of words that stipulation. c) Eliminate the words in a certain order in a systematic but when words in a certain order that is the place names, proper names, numbers, dates, months, years or the term, the word was surpassed and have the next word. This is done because the words were hard to guess based on the context of the sentence. This is called the modified fixed-ratio method. This method is widely used for the discourse that contains many of the terms or proper names.

$$
\text { According to Sitepu }
$$

(https://bintangsitepu.wordpress.com)

Cloze test is then also used to test reading comprehension, was originally created to test readability. Through this test can be seen the difficulty of potential users in filling vacated words (gaps) on a regular basis in a breakdown. The closer the words are emptied, it may be more difficult to do about it, and vice versa. The word is discarded (emptied) usually every word the fifth or seventh. Due to the selected word may be said that the same meaning (synonyms) with the original word, then that word synonyms can also be true. However, if the expected word is a word that is loaded exactly the same as the original word (word removed) then the initial letters of the words and letters written next emptied. The fewer mistakes made by filling the test, means that the higher the level of legibility of the text and vice versa, the more mistakes being made means that the lower the level of readability.

According Sejnost \& Thiese (2007: 15) the procedures taken in using this test is as follows: a) Choose three descriptions in the script or the book at random, each at the beginning, middle and end. Description chosen should stand alone and intact in the sense of having a concept or idea. Description length of approximately 250 words. b) Description of selected should be of interest to potential users. c) Avoid description of the many uses of proper names, such as names of people and place names. d) Copy back each description with the following provisions: Give a title to each 
description to provide an overview of the contents of the description, rewrite the first sentence of each description as a whole to provide more specific description of the contents description. For subsequent sentences, exhaust every word to five or seven words on a regular term. Repeated words counted until two words. If the reader is expected to fill the vacated word exactly as the original word, write the first letters of the word and is followed by the strip as much as the remaining letters of the word, for example, the "market" word is removed, it is written ( $\mathrm{M}_{-}{ }_{-}{ }_{-}-{ }_{\text {). Write the last }}$ sentence of each description as a whole to give an overview of what more complete description. Select randomly as little as ten prospective users of the manuscript to work on that test. Give clear instructions, including the purpose test given that they want to know on their reading skills but not the reading level text itself. Words are emptied is filled with one word that is considered most appropriate for the purpose of the sentence and the description, the overall difficulty level of the text can be seen from the number of words correctly loaded on the test.

Cloze Test results using these can be categorized as follows. Number of words in the correct level of difficulty a)> 50\% "Easy" in the sense that the reader understand the content of reading. b)> 35\% - 50\% "Difficult" in the sense that readers need help to understand the content of reading. c) $<35 \%-35 \%$ "Very Difficult", in the sense that the reader cannot understand the content of reading. (Sejnost \& Thiese, 2007: 15)

The results of such tests can be viewed individually and groups. Can occur the results of each individual is significantly different because of the background and a different experience. Thus, it may be just a matter of reading very difficult for some people but it is very easy for other people in the same group. Related to the reading materials used in the classroom, the average yield in the group is usually used.

Cloze Test aims to measure the level of mastery of pragmatic abilities, namely the ability to understand the discourse on the basis of linguistic ability and extra linguistic use. Measuring the level of mastery of pragmatic abilities is done by assigning the test participants to recognize, and to restore the original, parts of a discourse that has been eliminated.

\section{Reading Comprehension}

Comprehension is a word that usually used for understanding. When we read a passage, at the same time we push our mind to understand it. Comprehension is a term which is directly related to the ability of understanding of a passage. Therefore comprehension is very important for students as ability to know what a passage tells about.

Comprehension is the art of understanding of reading and it is a process to make sense from the writer's ideas through an interaction with the written text. Reading with comprehension means to understand what has been read. An active, thinking process depends not only on comprehension skills but also on the student's experiences and prior knowledge. Comprehension involves understanding vocabulary seeing the relationship among word and concepts, organizing ideas, recognizing the author's purpose, making judgment and evaluating.

Reading comprehension is understanding a text that is read, or the process of constructing meaning from a text. Comprehension is a construction process because it involves all the elements of the reading process working 
together as a text is read to create a representation of the text in the reader's mind. Reading comprehension means to understand what has been read. It is an active thinking process that depends not only on comprehension skill but also on the student's experience and prior knowledge.

To understand students' problems in reading comprehension and to plan an effective developmental program in reading, the teacher needs to know that various of skills that make up the ability to comprehend what is read, these specific skills may be classified according to the readers' purpose and the length and nature of the selection read.

Meanwhile reading with comprehension is not only depending on the reader, but it is related with multiple numbers of skills and abilities that are interrelated and interdependent. There are two reasons reading for comprehension. First, it is the most basic purpose for reading, underlying and supporting most other purposes for reading. Second, general reading comprehension is actually more complex than commonly assumed. Reading for comprehension when accomplished by a skill fluent reader, requires speed reading and automatic processing of words, strong skill in forming a general meaning representation of main ideas, and efficient coordination of many process under very limited time constrains.

Brown (2005:185) stated that there are two primary hurdles must be cleared in order to become efficient readers. First, they need to be able to master fundamental bottom-up strategies for processing separate letters, words, and phrases, as well as top down, conceptually driven strategies for comprehension. Second, second language readers must be develop appropriate content and formal schemata-background information and cultural experience to carry out those interpretation effectively.

\section{METHODOLOGY}

The method used in this study is a comparative descriptive method. Comparative research is a kind of descriptive study to find answers fundamentally about cause and effect, by analyzing the factors that cause the occurrence or appearance of a particular phenomenon

This method was selected on the consideration that the comparative descriptive method as activities to test the hypothesis and answer questions concerning the circumstances in the present of a study. Moreover, it is well designed both two types of test on student's reading comprehension by enclosing the table of research design below:

\begin{tabular}{|c|c|c|}
\multicolumn{3}{|c}{ Research Design } \\
\hline Type of Test & A & B \\
\hline $\begin{array}{c}\text { Student's } \\
\text { Reading } \\
\text { Comprehension }\end{array}$ & X1 & X2 \\
\hline
\end{tabular}

Note:

A : Multiple Choice Test

B : Cloze Task

X1 : Result of Student's Reading Comprehension by using Multiple Choice Test

X2 : Result of Student's Reading Comprehension by using Cloze Task

\section{FINDINGS}

Based on the analysis of research conducted on the different forms of the student's reading comprehension test on 30 students of fourth semester of English Department students at University of 
Indraprasta PGRI in the academic year 2015-2016 had different results. It can be seen from the results of the data analysis calculation that values Multiple Choice reading comprehension, the average (mean) of 69.3, the median value 64.49, mode was 62.1 and standard deviation 13:40. This shows that the ability of students' reading comprehension when using multiple choice tests are classified sufficient although they still need improvement. Comparison tests between multiple choice and cloze tests can be seen on the following table.

\begin{tabular}{|c|c|c|}
\hline Score & $\begin{array}{c}\text { Multiple } \\
\text { Choice }\end{array}$ & $\begin{array}{c}\text { Cloze } \\
\text { Task }\end{array}$ \\
\hline Mean & 69.3 & 55.6 \\
\hline Median & 66.14 & 52.86 \\
\hline Mode & 59.18 & 50 \\
\hline $\begin{array}{c}\text { Standard } \\
\text { Deviation }\end{array}$ & 13.40 & 9.97 \\
\hline Variant & 179.56 & 99.35 \\
\hline
\end{tabular}

The table above is a statistical summary of the mean, median, mode, standard deviation and variance between the results of reading comprehension test Multiple Choice and Cloze Task. It can be seen that the value of the Cloze task is lower than the value of Multiple Choice reading comprehension test.

From the calculation in the previous step, it is known that there are so many different significant results both Multiple Choice test and Cloze Task. Based on the two different results, so the ratios of all average scores in a data set (mean) analyzed by using "t-testing". Hypothesis testing of the research is conducted to know whether both tests are significantly different or not. Sequences of steps for counting hypothesis testing are drawn as follows:

$$
\mathbf{t}=\frac{\bar{X}_{A}-\bar{X}_{B}}{\sqrt{\frac{\sum X_{A}{ }^{2}+\sum X_{B}{ }^{2}}{n_{A}+n_{B}-2}\left(\frac{1}{n_{A}}+\frac{1}{n_{B}}\right)}}
$$

$$
\begin{aligned}
& t=\frac{69.3-55.6}{\mathrm{H} \frac{13.40}{30}+\frac{9.97}{30}} \\
& t=\frac{13.7}{\mathrm{H} \overline{0.45+0.33}} \\
& t=\frac{13.7}{\mathrm{H} \overline{0.78}} \\
& t=15.56
\end{aligned}
$$

The value of $t_{\text {table }}$ at significance grade $5 \%$ and degree of freedom (df) 58 is 1,67 , meanwhile $t_{\text {observed }}$ is 15.56 , so that $t_{\text {observed }}>t_{\text {table }}, H_{o}$ is rejected and $H_{a}$ is accepted.

The result of ratio counted by using $\mathrm{t}$ testing can be described in the following table:

\begin{tabular}{|c|c|c|c|}
\hline $\mathbf{N}$ & $\mathbf{t}_{\text {observed }}$ & $\mathbf{t}_{\text {table }}$ & \multicolumn{1}{|c|}{ Explanation } \\
\hline 58 & 15.56 & 1,67 & $\begin{array}{l}\mathrm{t}_{\text {observed }}>\mathrm{t}_{\text {table }} \\
\mathrm{H}_{\mathrm{o}} \text { is rejected } \\
\text { and } \mathrm{H}_{\mathrm{a}} \text { is } \\
\text { accepted. }\end{array}$ \\
\hline
\end{tabular}

From the table above, $t_{\text {observed }}$ is $15.56, t_{\text {table }} 1,67$ at significance grade $5 \%$ ( $\alpha=0,05)$ by (df) degree of freedom $\left(n_{A}+n_{B}-2\right)$. Therefore, $t_{\text {observed }}>t_{\text {table }}, H_{o}$ is rejected and $\mathrm{H}_{\mathrm{a}}$ is accepted. This means that there is significant difference between Multiple Choice test and Cloze Task on Student's Reading Comprehension.

\section{CONCLUSION}

This summary of the different types of assessment that can be used for measuring development in reading skills in the hopes that teachers or lecturers will better understand how single skills can be assessed by multiple measures. The description of the various assessment techniques may also help them to design their own classroom assessments, and may help to better understand the district or campus 
assessments that are already being used with their students. Each of the elements of the framework is briefly described, and descriptions of various forms of assessments that could be used for that framework element are provided.

Based on the result of research conducted, it can be concluded that the level of student's reading comprehension test upon 30 students of English Department at University of Indraprasta PGRI is in a "sufficient" category which indicated from the average value of students was 69.3. The using of Multiple Choice test has an impact on learning outcomes of students reading comprehension due to the form of this test allows students to answer and understand the contents of a problem given. Therefore, from the quantitive information and theory, it is clearly stated that there is a significant difference between the results of Multiple Choice test and Cloze Task form on student's reading comprehension.

\section{BIBLIOGRAPHY}

Brown, H D. (2004). Languange Assesment Principles and
Classroom Practice. USA:

Pearson Education, Inc

Dubay, W. H. (2004). The Principles of Readability. Costa Mesta: CA

Pramono, S. (2014). Panduan Evaluasi Kegiatan Belajar-Mengajar. Yogyakarta: Diva Press.

Uno, H.B. (2014). Perencanaan Pembelajaran.Jakarta: PT.Bumi Aksara.

Uno, H.B dan Satria K. (2014). Assesment Pembelajaran. Jakarta: PT. Bumi Aksara

Ratnawulan, E. dan H.A Rusdiana. (2015). Evaluasi Pembelajaran. Bandung: CV. Pustaka Setia

Sejnost, R. L., dan Thiese, S. (2007). Creating the framework for reading. In Reading and writing across content areas. ( $2^{\text {nd }}$ ed., $p$. 1-35). Thousand Oaks, CA: Corwin Press.

https://bintangsitepu.wordpress.com accessed on April 23 ${ }^{\text {rd }} 2016$, 20.00 WIB 